\title{
EVALUASI KESEIMBANGAN AIR DI PROVINSI JAWA TENGAH
}

\author{
Oleh: \\ Sutopo Purwo Nugroho
}

Peneliti Bidang Teknologi Pengembangan Sumber Daya Alam, BPPT.

\begin{abstract}
Water supply for the domestics use of Central Java Province has been experiencing problems and challenging. With population of 35 million or $16 \%$ of Indonesia, it place the province as the third in national population. It have consequently, water need in the province is as such for use of domestics, irrigation/agriculture, industry, etc. Several counties within the province has experiencing water shortage. Particularly during dry season, defisits is inclining that results water use conflicts. Furthermore, conflicts occur not only in counties with water shortage but also in county with sufficient water supply. Conflict is generally triggered by weak management and allocation. This is a result of unlimited territorial sovereighnity of water resources and uncertainty of water rights. Unlimited territorial sovereighnity of water resource contain exclusive right to utilize tap water within the territorial right, in way that the territory hold the sole right to exploit the resource without compensation to neighbouring territory. Hence, water balance should be investigated better and comprehensively.
\end{abstract}

Kata kunci: keseimbangan air, konflik, sumber daya air, Jawa Tengah.

\section{PENDAHULUAN}

Air merupakan sumberdaya alam yang strategis dan vital bagi kehidupan manusia dan pembangunan, serta keberadaannya tidak dapat digantikan oleh materi lainnya. Air dibutuhkan untuk menunjang berbagai sistem kehidupan, baik dalam lingkup atmosfir, litosfir, dan biosfir. Hampir semua kebutuhan hidup manusia membutuhkan air, baik untuk kebutuhan rumah tangga (domestik), pertanian, industri, dan kegiatan ekonomi lainnya. Pasokan air untuk mendukung berjalannya pembangunan dan berbagai kebutuhan manusia perlu dijamin kesinambungannya, terutama yang berkaitan dengan kuantitas dan kualitasnya sesuai dengan yang dibutuhkan.

Ketersediaan air relatif tetap walau bervariasi menurut ruang dan waktu, sedang kebutuhan air cenderung terus meningkat mengikuti peningkatan jumlah penduduk serta taraf hidup sebagai hasil pembangunan. Keadaan ini diperkirakan telah menimbulkan ketimpangan di berbagai daerah yang menyangkut pasokan dan kebutuhan air. Saat ini satu dari empat orang di dunia kekurangan air minum dan satu dari tiga orang tidak mendapat sarana sanitasi yang layak (Bouwer, 2000). Menjelang tahun 2025, sekitar 2,7 milyar orang atau sekitar sepertiga populasi dunia akan menghadapi kekurangan air dalam tingkat yang parah (Dinar, 1998).

Memang sudah sejak awal diprediksikan, bahwa pada abad 21 air akan menjadi isu besar dunia dan penyebab timbulnya konflik, jika tidak segera diatasi secara menyeluruh. Kondisi krisis air di dunia terus meningkat dalam tiga dekade terakhir. Sejak memasuki abad 21, krisis air terus berlangsung dengan laju peningkatan yang tidak dapat diperkirakan (Giordano et al., 2004). Jika pada tahun 1950-an hanya sedikit negaranegara yang menghadapi kekurangan air. Namun hingga akhir tahun 1990-an, jumlah negara-negara yang mengalami defisit air meningkat dengan jumlah penduduk sekitar 300 juta jiwa(Gleick, 1999). Diperkirakan 2/3 penduduk dunia akan mengalami kekurangan air pada tahun 2050 jika tidak segera ditanggulanginya (Abu-Zeid, 1998).

Secara nasional, ketersediaan air di Indonesia mencapai 1.957 miliar meter kubik per tahun. Dengan jumlah penduduk sekitar 220 juta jiwa, potensi tersebut setara dengan sekitar 8.800 meter kubik per kapita per tahun. Masih di atas rata-rata dunia yang hanya 8.000 meter kubik per kapita per tahun. Namun demikian, kondisi ketersediaan air per wilayah dan waktu bervariasi. Lebih dari 83 persen aliran permukaan terkonsentrasi di Sumatera, Kalimantan, dan Papua, sedangkan 17 persen lainnya di Jawa-Bali, Sulawesi, dan Nusa Tenggara. Pulau Jawa dengan luas 7 persen dari total daratan wilayah Indonesia hanya memiliki potensi air tawar 4,5 persen dari total nasional. Namun demikian penduduk di pulau Jawa mencapai sekitar 59 persen dari total penduduk Indonesia. Jelas, kondisi tersebut menggambarkan bahwa potensi kelangkaan air 
yang sangat besar akan terjadi di Jawa dengan daya dukung sumber daya air yang telah mencapai titik kritis.

Hal ini terlihat dari data keseimbangan air tahun 2003 dimana dari total kebutuhan air di Pulau Jawa dan Bali sebesar 38,4 miliar meter kubik pada musim kemarau, hanya dapat dipenuhi sekitar 25,3 miliar kubik atau hanya sekitar 66 persen. Defisit ini diperkirakan akan semakin tinggi pada tahun 2020, dimana jumlah penduduk dan aktifitas perekonomian meningkat secara signifikan.Diperkirakan pada tahun 2020 total potensinya tinggal $1.200 \mathrm{~m}^{3} / \mathrm{kapita} /$ tahun, dimana hanya $35 \%$ dari potensi alami tersebut yang layak secara ekonomis untuk dikelola. Maka potensi aktualnya tinggal 400 $\mathrm{m}^{3} / \mathrm{kapita}$ /tahun. Potensi ini jauh di bawah standar angka minimum yang ditetapkan PBB yaitu sebesar $1.100 \mathrm{~m}^{3} / \mathrm{kapita}$ /tahun (Nugroho, 2002, 2007).

Kondisi demikian juga terjadi di Provinsi Jawa Tengah, dimana jumlah penduduk dan pembangunan terus meningkat. Penduduk Jawa Tengah sekitar 35 juta jiwa atau sekitar $16 \%$ dari jumlah penduduk Indonesia. Ini menempatkan Jawa Tengah sebagai propinsi ketiga di Indonesia dengan jumlah penduduk terbanyak di samping Jawa Timur dan Jawa Barat. Sektor pertanian dimasuki sekitar $42 \%$ pekerja dan merupakan sektor terbanyak yang menyerap pekerja. Sektor lain yang cukup banyak menyerap pekerja adalah sektor perdagangan dan sektor industri, masing-masing tercatat sebesar 19,35\% dan 17,36\%. Meningkatnya seluruh aktivitas penduduk tersebut tentu membawa konsekuensi pada semakin meningkatnya pasokan penyediaan air.

Oleh karena itu, pengelolaan sumberdaya air di Jawa Tengah di masa mendatang akan semakin menghadapi tantangan yang lebih berat. Kebutuhan akan penyediaan air yang mencakup kapasitas daya dukung serta tingkat perkembangan kebutuhan air semakin dirasakan mendesak dari waktu ke waktu, baik penyediaan air untuk kebutuhan domestik, pertanian, industri, pemukiman, dan sektor lainnya. Konflik antar berbagai kebutuhan air semakin sering terjadi, di samping akibat dampak pencemaran karena terlampauinya daya dukung sumberdaya air yang ada. Kebijakan penyediaan air di masa mendatang sangat ditentukan oleh besaran jumlah penduduk dan tingkat kesejahteraan rakyat pada saat itu. Untuk itulah keseimbangan air perlu ditemukenali agar alternatif penanggulangan dan potensi konflik dapat diminimumkan.

\section{METODE PENELITIAN}

Penelitian ini bersifat deskriptif - kuantitatif dan kualitatif yang menekankan pada penggambaran dan pemahaman fenomena yang kompleks pada hubungan antar faktor yang berpengaruh. Penelitian ini tidak menghitung keseimbangan air secara langsung, namun berdasarkan berbagai studi literatur yang ada. Sebab hingga saat ini sudah pernah dilakukan perhitungan keseimbangan air untuk Jawa Tengah dengan berbagai metode sesuai dengan tujuannya. Data dan informasi berdasarkan studi literatur diharapkan dapat saling menutupi kelemahan dan melengkapi data/informasi yang dibutuhkan serta menangkap realitas masalah menjadi lebih diandalkan. Dengan studi literatur akan diketahui sampai dimana terdapat kesimpulan dan generalisasi yang telah pernah dibuat sehingga situasi yang diperlukan dapat diperoleh (Sitorus, 1989; Nazir, 1999).

Berdasarkan hasil penelusuran literatur yang ada maka diperlukan adanya validasi data dan informasi agar dapat saling menutupi kelemahan dan melengkapi data/informasi yang dibutuhkan sehingga dapat menangkap realitas masalah menjadi lebih valid. Validasi dalam analisis keseimbangan air didasarkan pada keseimbangan air yang merupakan suatu gambaran umum mengenai kondisi ketersediaan air dan pemanfaatannya di suatu daerah.

\section{HASIL DAN PEMBAHASAN}

Potensi sumberdaya air provinsi Jawa Tengah sekitar 65.733,75 juta $\mathrm{m}^{3} /$ tahun. Dari potensi tersebut yang termanfaatkan baru sekitar $41,97 \%$, yaitu untuk pemenuhan kebutuhan air sekitar 25.282,16 juta $\mathrm{m}^{3} /$ tahun $(38,46 \%)$ dan $2.308,38$ juta m3/tahun $(3,51 \%)$ yang berada di waduk, embung dan badan air lainnya. Sedangkan sisanya tak termanfaatkan yang berupa debit aliran yang terbuang ke laut sekitar $37.628,67$ juta $\mathrm{m}^{3} /$ tahun $(57,24 \%)$ dan air tercemar sekitar 514,54 juta $\mathrm{m}^{3} /$ tahun $(0,78 \%)$ (Sudanti, 2002). Hasil perhitungan tersebut menunjukkan bahwa secara akumulatif, potensi air lebih besar dari pada total kebutuhan air, sehingga tidak ada masalah berkaitan dengan penyediaan air. Disinilah salah satu kelemahan dari perhitungan keseimbangan air dengan basis provinsi, dimana bersifat makro sehingga kurang mencerminkan permasalahan yang sebenarnya. Padahal jika dihitung secara lebih detil dengan satuan/unit kabupaten akan terlihat bahwa banyak daerah yang mengalami krisis air.

Berdasarkan klasifikasi status sumberdaya air dikelompokkan menjadi 4 kelompok, yaitu aman, waspada, kritis dan lewat kritis. Status aman adalah total kebutuhan air masih kurang dari kondisi aliran rendah $10 \%$. Status waspada adalah total kebutuhan air di antara kondisi aliran rendah $10 \%$ dan $25 \%$. Status kritis adalah total kebutuhan air ada di antara kondisi aliran rendah 25 dan 45\%. Sedangkan status lewat kritis 
adalah total kebutuhan air lebih besar dari kondisi aliran rendah $45 \%$.

Dalam perhitungan keseimbangan air dengan pendekatan supply-demand, ukuran yang biasa digunakan untuk evaluasi status potensi sumberdaya air suatu wilayah adalah dengan membandingkan tingkat debit andalan dengan total kebutuhan air yang ada. Debit andalan yang digunakan umumnya adalah $25 \%$ dari debit rerata, yang diandaikan sebagai kondisi aliran rendah yang mungkin dijumpai pada tahun-tahun kering berkepanjangan, sehingga untuk kebanyakan tahun debit aliran permukaan atau sungai akan lebih tinggi dari nilai ini. Hasil kajian Bank Dunia memberikan debit andalan 45\% debit rerata yang setara dengan tahun kering lima tahunan (Pawitan dkk., 2002)

Mengacu pada pengelompokan status sumberdaya air tersebut maka dari 29 kabupaten di Jawa Tengah, hanya 3 kabupaten yang kondisi ketersediaan airnya tergolong dalam aman, bahkan hingga prediksi tahun 2020, yaitu kabupaten Banjarnegara, Wonosobo dan Karanganyar. 17 kabupaten memiliki kondisi waspada, dan 8 kabupaten kondisinya kritis, sedangkan 1 kabupaten lewat kritis yaitu kabupaten Demak. Untuk kota di seluruh Jawa Tengah kondisinya sudah lewat kritis (Tabel 1).

Tabel 1 : Keseimbangan Air Dan Status Kekritisan Sumberdaya Air Per Kabupaten Di Jawa Tengah.

\begin{tabular}{|c|c|c|c|c|c|c|c|c|c|c|c|c|}
\hline \multirow[t]{2}{*}{ No } & \multirow[t]{2}{*}{$\mathrm{Kab}$} & \multirow{2}{*}{$\begin{array}{c}\text { Total air } \\
\text { Tersedia } \\
\text { (MCM) }\end{array}$} & \multicolumn{3}{|c|}{ Aliran Rendah (MCM) } & \multirow{2}{*}{$\begin{array}{l}\text { Kebutuhan } \\
\text { Irigasi } \\
\text { (MCM) }\end{array}$} & \multicolumn{3}{|c|}{ Kebutuhan DMI (MCM) } & \multicolumn{3}{|c|}{ Status } \\
\hline & & & $10 \%$ & $25 \%$ & $45 \%$ & & 2000 & 2010 & 2020 & 00 & 10 & 20 \\
\hline 1 & Cilacap & 2146 & 186 & 466 & 839 & 689 & 34.12 & 35.69 & 37.32 & 2 & 2 & 2 \\
\hline 2 & Banyumas & 3575 & 312 & 779 & 1403 & 367 & 30.52 & 31.49 & 32.49 & 1 & 1 & 1 \\
\hline 3 & Purbalingga & 1905 & 166 & 415 & 746 & 233 & 16.55 & 17.06 & 17.59 & 1 & 1 & 1 \\
\hline 4 & Banjarngr & 3044 & 266 & 664 & 1195 & 151 & 18.11 & 19.37 & 20.71 & 0 & 0 & 0 \\
\hline 5 & Kebumen & 1817 & 158 & 395 & 711 & 410 & 25.05 & 25.53 & 26.02 & 2 & 2 & 2 \\
\hline 6 & Purworejo & 2320 & 202 & 504 & 908 & 319 & 15.42 & 15.50 & 15.58 & 1 & 1 & 1 \\
\hline 7 & Wonosobo & 6950 & 608 & 1518 & 2734 & 180 & 15.19 & 15.81 & 16.45 & 0 & 0 & 0 \\
\hline 8 & Magelang & 2180 & 189 & 473 & 851 & 335 & 22.71 & 23.15 & 23.59 & 1 & 1 & 1 \\
\hline 9 & Boyolali & 1562 & 135 & 338 & 609 & 236 & 18.79 & 19.07 & 19.36 & 1 & 1 & 1 \\
\hline 10 & Klaten & 1019 & 88 & 220 & 395 & 362 & 24.24 & 24.69 & 25.16 & 2 & 2 & 2 \\
\hline 11 & Sukoharjo & 729 & 63 & 157 & 283 & 238 & 16.19 & 17.75 & 19.47 & 2 & 2 & 2 \\
\hline 12 & Wonogiri & 2819 & 243 & 608 & 1094 & 243 & 21.53 & 22.08 & 22.63 & 1 & 1 & 1 \\
\hline 13 & Kr.Anyar & 2423 & 297 & 743 & 1337 & 249 & 16.58 & 17.95 & 19.42 & 0 & 0 & 0 \\
\hline 14 & Sragen & 1735 & 150 & 376 & 677 & 462 & 18.50 & 18.91 & 19.33 & 2 & 2 & 2 \\
\hline 15 & Grobogan & 2969 & 256 & 639 & 1151 & 479 & 26.79 & 28.48 & 30.28 & 1 & 1 & 1 \\
\hline 16 & Blora & 2648 & 228 & 570 & 1026 & 371 & 17.38 & 17.96 & 18.55 & 1 & 1 & 1 \\
\hline 17 & Rembang & 1229 & 105 & 263 & 473 & 221 & 12.22 & 13.27 & 14.41 & 1 & 1 & 1 \\
\hline 18 & Pati & 2655 & 230 & 574 & 1034 & 591 & 23.91 & 24.50 & 25.10 & 2 & 2 & 2 \\
\hline 19 & Kudus & 1013 & 88 & 220 & 397 & 138 & 15.29 & 16.88 & 18.63 & 1 & 1 & 1 \\
\hline 20 & Jepara & 1912 & 166 & 414 & 745 & 205 & 20.14 & 22.32 & 24.74 & 1 & 1 & 1 \\
\hline 21 & Demak & 1187 & 102 & 254 & 458 & 452 & 20.70 & 23.71 & 27.16 & 3 & 3 & 3 \\
\hline 22 & Semarang & 1843 & 160 & 399 & 718 & 212 & 17.98 & 18.76 & 19.57 & 1 & 1 & 1 \\
\hline 23 & Tmanggung & 1901 & 165 & 413 & 743 & 168 & 14.08 & 14.62 & 15.19 & 1 & 1 & 1 \\
\hline 24 & Kendal & 2105 & 183 & 457 & 823 & 293 & 18.71 & 19.97 & 21.31 & 1 & 1 & 1 \\
\hline 25 & Batang & 2014 & 175 & 439 & 789 & 211 & 13.57 & 14.20 & 14.85 & 1 & 1 & 1 \\
\hline 26 & Pkalongan & 2995 & 261 & 651 & 1172 & 272 & 16.03 & 16.74 & 17.49 & 1 & 1 & 1 \\
\hline 27 & Pemalang & 2857 & 249 & 623 & 1122 & 393 & 27.03 & 29.86 & 32.99 & 1 & 1 & 1 \\
\hline 28 & Tegal & 1573 & 136 & 340 & 613 & 368 & 28.72 & 30.34 & 32.05 & 2 & 2 & 2 \\
\hline 29 & Brebes & 1884 & 163 & 408 & 734 & 521 & 37.66 & 42.41 & 47.77 & 2 & 2 & 2 \\
\hline
\end{tabular}

Sumber: Pawitan dkk., 1996

Keterangan :

$0=$ = Status aman dimana total kebutuhan air masih kurang dari kondisi aliran rendah $10 \%$

1 = Status waspada dimana total kebutuhan air di antara kondisi aliran rendah $10 \%$ dan $25 \%$

2 = Status kritis dimana total kebutuhan air di antara kondisi aliran rendah $25 \%$ dan $45 \%$

$3=$ Status lewat kritis dimana total kebutuhan air lebih besar dari kondisi aliran rendah $45 \%$

$\mathrm{MCM}=$ mega cubic meter

Dalam perhitungan keseimbangan air tersebut potensi air tanah sudah diperhitungkan. Namun untuk pemenuhan kebutuhan air irigasi pemenuhan dilakukan berdasarkan debit sungai andalan yang ada. Kelemahan metode ini mengasumsikan seluruh debit andalan yang ada dapat diperuntukkan untuk pemenuhan segala jenis kebutuhan air dan berlaku untuk seluruh wilayah kabupaten/kota. Selain itu kurang memberikan informasi sebaran dan durasi dari status sumberdaya air dalam rentang waktu selama setahun. Namun demikian hasil perhitungan tersebut sangat bermanfaat untuk memberikan gambaran mengenai agihan dari keseimbangan air per kabupaten/kota di Jawa Tengah. 


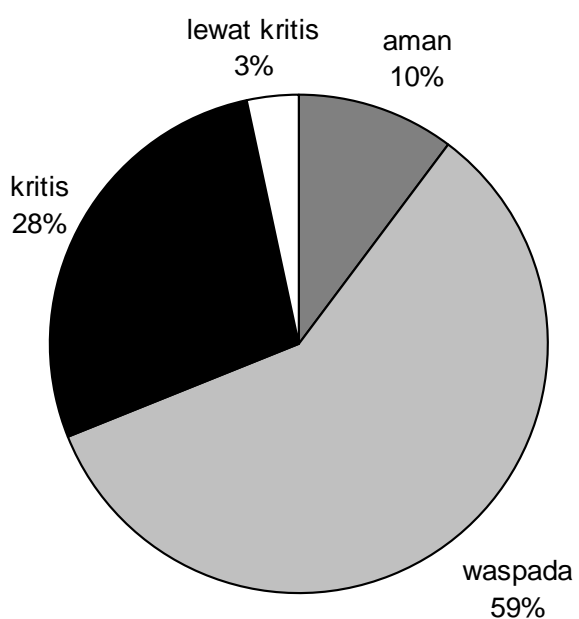

Gambar 1 : Perbandingan Prosentase Status Sumber Daya Air Per Kabupaten Di Jawa Tengah

Hasil perhitungan keseimbangan air tersebut ternyata cukup berbeda dibandingkan dengan kajian yang dilakukan Bappenas tahun 2005. Di Pulau Jawa untuk wilayah di luar Jabodetabek ditemukan bahwa pada tahun 2003 sebagian besar (sekitar 77 persen) kabupaten telah memiliki satu hingga delapan bulan defisit air dalam setahun. Pada tahun 2025 jumlah kabupaten defisit air meningkat hingga mencapai sekitar 78,4 persen dengan defisit berkisar mulai dari satu hingga dua belas bulan, atau defisit sepanjang tahun. Dari wilayah yang mengalami defisit tersebut, terdapat 38 kabupaten/kota atau sekitar 35 persen yang pada tahun 2003 telah mengalami defisit tinggi. Dalam hal ini, kondisi keseimbangan air diklasifikasi menjadi empat yaitu normal, defisit rendah, defisit sedang, dan defisit tinggi. Kondisi normal menunjukkan bahwa tidak terjadi defisit sepanjang tahun, sedangkan jika jumlah bulan defisit mencapai 3 bulan diklasifikasi sebagai defisit rendah, dari empat hingga enam bulan diklasifikasi defisit sedang, dan lebih dari enam bulan diklasifikasi defisit tinggi.

Di Jawa Tengah terdapat 10 kabupaten/kota yang memiliki defisit sedang hingga tinggi. Kabupaten Klaten merupakan kebupaten dengan tingkat defisit tinggi karena memiliki 8 bulan defisit air (Tabel 2). Hal ini sangat mengkhawatirkan karena kabupaten Klaten merupakan daerah lumbung padi untuk Jawa Tengah dan memiliki lahan pertanian yang sangat subur. Namun adanya konversi lahan pertanian sawah menjadi permukiman dan industri kebutuhan air untuk pertanian menjadi berubah. Ditinjau dari aspek ketersediaan air, defisit air yang terjadi selama 8 bulan merupakan hal yang sangat ironis. Sebab di beberapa daerah di Kabupaten Klaten terdapat sumber mataair dengan debit cukup besar di sekitar lereng gunungapi Merapi. Bahkan di sekitar daerah Cokrotulung mataair yang ada dieksploitasi menjadi air kemasan. Hal ini juga telah menyebabkan kekeringan di sebagian sawah di sekitar daerah tersebut. Dengan adanya defisit air tersebut, maka konflik kepentingan penggunaan air akan semakin tinggi di masa mendatang.

Tabel 2 : Kabupaten/Kota Di Jawa Tengah Yang Memiliki Defisit Sedang - Tinggi.

\begin{tabular}{|c|c|c|c|c|c|c|c|c|c|c|c|c|c|c|}
\hline \multirow[t]{2}{*}{ No } & \multirow[t]{2}{*}{ Kab/Kota } & \multicolumn{2}{|c|}{ Wilayah Sungai } & \multicolumn{5}{|c|}{ Jumlah Bulan Defisit } & \multicolumn{6}{|c|}{ Defisit maksimum (m3/det) } \\
\hline & & WS & Luas & 2005 & 2010 & 2015 & 2020 & 2025 & 2005 & 2005 & 2010 & 2015 & 2020 & 2025 \\
\hline \multirow{3}{*}{1} & \multirow{3}{*}{ Magelang } & Progo-Opak-Oyo & $96.90 \%$ & \multirow{3}{*}{7} & \multirow{3}{*}{7} & \multirow{3}{*}{7} & \multirow{3}{*}{7} & \multirow{3}{*}{7} & \multirow{3}{*}{7} & \multirow{3}{*}{-25.85} & \multirow{3}{*}{-26.2} & \multirow{3}{*}{-26.59} & \multirow{3}{*}{-27.05} & \multirow{3}{*}{-27.57} \\
\hline & & Jratunseluna & $0.40 \%$ & & & & & & & & & & & \\
\hline & & Serayu & $2.60 \%$ & & & & & & & & & & & \\
\hline \multirow[t]{2}{*}{2} & \multirow[t]{2}{*}{ Klaten } & Progo-Opak-Oyo & $2.00 \%$ & \multirow[t]{2}{*}{8} & \multirow[t]{2}{*}{8} & \multirow[t]{2}{*}{8} & \multirow[t]{2}{*}{8} & \multirow[t]{2}{*}{8} & \multirow[t]{2}{*}{8} & \multirow[t]{2}{*}{-32.58} & \multirow[t]{2}{*}{-32.63} & \multirow[t]{2}{*}{-32.71} & \multirow[t]{2}{*}{-32.83} & \multirow[t]{2}{*}{-32.99} \\
\hline & & Bengawan Solo & $98.00 \%$ & & & & & & & & & & & \\
\hline 3 & Sukoharjo & Bengawan Solo & $100 \%$ & 6 & 6 & 6 & 6 & 6 & 6 & -16.64 & -16.66 & -16.67 & -16.75 & -16.91 \\
\hline 4 & Karanganyar & Bengawan Solo & $100 \%$ & 7 & 7 & 7 & 7 & 7 & 7 & -18.44 & -18.27 & -18.14 & -18.04 & -17.91 \\
\hline \multirow[t]{2}{*}{5} & Sragen & Jratunseluna & $25.90 \%$ & 7 & 7 & 7 & 7 & 7 & 7 & -20.77 & -21.17 & -21.66 & -22.7 & -23.03 \\
\hline & & Bengawan Solo & $74.10 \%$ & & & & & & & & & & & \\
\hline 6 & Blora & Jratunseluna & $44.70 \%$ & 6 & 6 & 6 & 6 & 6 & 6 & -12.94 & -13 & -13.07 & -13.14 & -13.22 \\
\hline & & Bengawan Solo & $55.30 \%$ & & & & & & & & & & & \\
\hline 7 & Pekalongan & Pemali-Comal & $99.80 \%$ & 6 & 6 & 6 & 6 & 6 & 6 & -11.48 & -11.56 & -11.67 & -11.8 & -11.94 \\
\hline & & Serayu & $0.20 \%$ & & & & & & & & & & & \\
\hline 8 & Kota Semarang & Jratunseluna & $100 \%$ & 6 & 6 & 6 & 6 & 6 & 6 & -2.58 & -3.2 & -4.05 & -5.2 & -6.76 \\
\hline 9 & Kota Pekalongan & Pemali-Comal & $100 \%$ & 6 & 6 & 6 & 6 & 6 & 7 & -1.1 & -1.18 & -1.27 & \begin{tabular}{|c|}
-1.38 \\
\end{tabular} & -1.51 \\
\hline 10 & Temanggung & Jratunseluna & $41.00 \%$ & 5 & 5 & 5 & 5 & 5 & 6 & -19.13 & -19.25 & -19.37 & -19.51 & -19.66 \\
\hline
\end{tabular}

Sumber: Bappenas, 2005

Di antara kabupaten/kota yang mengalami defisit air tersebut, saat ini telah mengalami defisit penyediaan air minum. Menurut Bappenas (2005), defisit air minum hanya terjadi di kabupaten Magelang, Klaten, Sragen dan Kota Semarang. Hal ini jelas sangat berbeda dengan kondisi sesungguhnya di lapangan. Sebab saat ini defisit air minum hampir terjadi di kota-kota besar di Jawa Tengah. Terlebih pada saat kemarau, dimana pasokan air dari sungai semakin berkurang sehingga penyediaan air dari PDAM menjadi tidak mencukupi. Demikian pula 
halnya dengan daerah-daerah yang mempunyai kondisi hidrogeologi yang secara alamiah cadangan airtanah sangat terbatas. Jumlah ini diperkirakan semakin meningkat apabila tidak dilakukan intervensi infrastruktur. Kondisi ini perlu mendapatkan perhatian secara khusus dan perlu dilakukan upaya penanganan segera dalam jangka pendek. Kabupaten/kota yang mengalami defisit penyediaan air minum diuraikan pada Tabel 3.

Tabel 5 : Kabupaten/Kota Di Pulau Jawa Yang Mengalami Defisit Air Minum.

\begin{tabular}{|c|c|c|c|c|c|c|c|c|}
\hline \multirow[t]{2}{*}{ No } & \multirow[t]{2}{*}{ Kab/Kota } & \multicolumn{2}{|c|}{ Wilayah Sungai } & \multicolumn{5}{|c|}{ Defisit Air Minum Maksimum (m3/det) } \\
\hline & & WS & Luas & 2005 & 2010 & 2015 & 2020 & 2025 \\
\hline \multirow{3}{*}{1} & \multirow{3}{*}{ Magelang } & Progo-Opak-Oyo & $96.90 \%$ & & \multirow{3}{*}{-0.09} & \multirow{3}{*}{-0.35} & \multirow{3}{*}{-0.63} & \multirow{3}{*}{-0.94} \\
\hline & & \begin{tabular}{|l|l} 
Jratunseluna \\
\end{tabular} & $0.40 \%$ & & & & & \\
\hline & & Serayu & $2.60 \%$ & & & & & \\
\hline \multirow[t]{2}{*}{2} & \multirow[t]{2}{*}{ Klaten } & Progo-Opak-Oyo & $2.00 \%$ & \multirow[t]{2}{*}{-1.42} & \multirow[t]{2}{*}{-1.39} & \multirow[t]{2}{*}{-1.36} & \multirow[t]{2}{*}{-1.33} & \multirow[t]{2}{*}{-1.3} \\
\hline & & Bengawan Solo & $98.00 \%$ & & & & & \\
\hline \multirow[t]{2}{*}{3} & \multirow[t]{2}{*}{ Sragen } & Jratunseluna & $25.90 \%$ & & & & \multirow[t]{2}{*}{-0.3} & \multirow[t]{2}{*}{-0.083} \\
\hline & & Bengawan Solo & $74.10 \%$ & & & & & \\
\hline & Kota Semarang & Jratunseluna & $100 \%$ & & -0.11 & -0.55 & -1.06 & -1.63 \\
\hline
\end{tabular}

Sumber : Bappenas, 2005

Berdasarkan pada hasil perhitungan dan fakta di lapangan tersebut menunjukkan bahwa pengelolaan sumberdaya air perlu dilakukan secara lebih baik. Masalah penyediaan air merupakan salah satu bagian dari pengelolaan sumberdaya air. Oleh karena itu diperlukan pengelolaan sumberdaya air terpadu. Pengelolaan terpadu sumberdaya air adalah suatu proses yang mengedepankan pembangunan dan pengelolaan sumberdaya air, lahan, dan sumberdaya terkait lainnya secara terkoordinasi dalam rangka memaksimalkan resultan ekonomi dan kesejahteraan sosial secara adil tanpa mengorbankan keberlanjutan ekosistem yang vital. Prinsip pengelolaan terpadu sumberdaya air ini dikembangkan sebagai respon terhadap pola pengelolaan sumberdaya air yang diterapkan selama ini yang cenderung terfragmentasi sehingga menimbulkan kesulitan dalam mengkoordinasikan berbagai kebijakan dan program yang berdampak timbulnya berbagai persoalan seperti banjir, kekeringan, longsor, erosi, pencemaran, dan sebagainya.

Dalam hal ini. pengelolaan sumberdaya air berkelanjutan merupakan pengelolaan air yang bersifat multi dimensional mengenai hubungan antara sumber daya alam, sosial dan sistem ekonomi yang simultan dalam penggunaan dan pengelolaan air (Flint, 2003). Sistem sumberdaya air diatur untuk memenuhi perubahan terhadap kebutuhan air pada saat ini dan masa depan tanpa terjadi kerusakan lingkungan (Loucks, 2000). Pengelolaan air berkelanjutan merefleksikan aspek-aspek sosial, ekonomi, lingkungan, dan kelembagaan dari prinsip pembangunan berkelanjutan, misalnya dimensidimensi yang menyangkut jumlah dan kualitas air, perlindungan sumber air, distribusi air, akses masyarakat untuk memperoleh air, serta nilai manfaat air bagi masyarakat (Lundin et al., 1997).

Dengan semakin terbatasnya ketersediaan air di Jawa Tengah, maka potensi konflik penggunaan air semakin tinggi. Bahkan di beberapa tempat, seperti di Klaten, Boyolali, Solo dan sebagainya telah timbul konflik dalam perebutan air. Konflik selalu terjadi di dalam interaksi antara individu/kelompok/masyarakat dengan individu/kelompok/masyarakat lainnya untuk memanfaatkan sumberdaya alam yang sama. Perubahan kondisi sumberdaya alam dan lingkungan di suatu wilayah memiliki konsekuensi negatif terhadap wilayah-wilayah di sekitarnya dan memicu timbulnya konflik lingkungan antar wilayah. Spector (2001) mengklasifikasikan perubahan sumberdaya alam dan lingkungan yang potensial menjadi masalah lintas wilayah menjadi empat aspek, yaitu : terjadinya degradasi (polusi) lingkungan, adanya kelangkaan (scarcity/shortages) dari sumberdaya alam dan lingkungan, maladistribusi sumberdaya alam (inequitable allocation), dan bencana alam/lingkungan atau kecelakaan yang terjadi secara alami atau akibat perbuatan manusia. Keempat kategori tersebut semuanya terkait dengan ketersediaan sumberdaya alam. Di samping menyangkut ketersediaan sumberdaya alam, konflik lintas wilayah berinteraksi pula dengan masalah perbedaan politik, ekonomi, dan budaya.

Di Jawa Tengah, konflik penggunaan air pada umumnya terjadi akibat dari lemahnya manajemen dan alokasi air yang ada. Tidak jarang konflik terjadi pada daerah-daerah yang kondisi ketersediaan airnya melimpah. Konflik air 
minum lintas wilayah pada dasarnya menyangkut sistem manajemen dan alokasi air minum yang efisien dan adil (equitable), seperti variabilitas dan ketidakpastian pasokan air, ketergantungan (inter dependencies) di antara pemakai, serta peningkatan kelangkaan dan biaya pengadaan air minum (Frederick, 2001). Adapun pengaruh manusia sebagai akar dari konflik air minum adalah penurunan kualitas air dan ekosistem akuatik akibat kegiatan manusia, kegagalan menjadikan air sebagai komoditas ekonomi yang menyebabkan pemanfaatan air tidak efisien, serta kebutuhan air minum yang tidak seimbang dengan ketersediaan air minum yang ada.

Konflik air minum lintas wilayah di antara pengguna air yang secara administratif dan atau politis berbeda, berkaitan pula dengan masih kuatnya doktrin kedaulatan wilayah tanpa batas (unlimited territorial sovereignty) dan tidak jelasnya hak kepemilikan (property rights) dari sumberdaya air. Doktrin kedaulatan wilayah tanpa batas menyatakan bahwa wilayah memiliki hak eksklusif untuk memanfaatkan sumber air minum di dalam wilayahnya, sehingga wilayah tersebut merasa lebih berhak untuk mengeksploitasinya tanpa memberikan kompensasi terhadap wilayah lain yang dirugikannya. Akibat dari doktrin ini wilayah atau negara yang merasa dirugikan akan melakukan gugatan yang berujung kepada terjadinya konflik.

Kondisi yang hampir mirip terjadi dengan menguatnya kewenangan daerah untuk mengatur sumberdaya alam yang ada di dalam wilayah administratifnya. Daerah yang memiliki sumber air minum cenderung merasa lebih berhak untuk mengatur sistem pengelolaan air minumnya dibandingkan dengan daerah sekitarnya yang menggantungkan pasokan air dari padanya, misalnya tuntutan daerah hulu terhadap daerah hilir yang terjadi di beberapa wilayah di Jawa Tengah.

Sebaliknya, doktrin keterpaduan wilayah tidak terbatas (unlimited territorial integrity) yang merupakan kebalikan dari doktrin kedaulatan wilayah tanpa batas, menyatakan bahwa satu wilayah tidak berhak mengubah kuantitas dan kualitas dari ketersediaan air yang mengalir ke wilayah lainnya. Doktrin ini mengatur bagaimana pemanfaatan air di bagian hulu sehingga tidak mengganggu daerah lainnya, seperti diaplikasikan oleh Mesir terhadap negara-negara yang memiliki proyek-proyek air di sepanjang Sungai Nil yang diperkirakan akan mengurangi pasokan air ke Mesir (Frederick, 2001). Kedua doktrin tersebut tidak akan menghasilkan penggunaan air yang efisien apabila tidak diikuti oleh proses tawar (bargaining process) antar wilayah yang terlibat, misalnya doktrin pertama menjadikan India tidak berkeinginan untuk menyediakan insentif dalam mengurangi dampak polusi air sungai yang dirasakan oleh Banglades.
Posisi tawar dalam alokasi sumber air minum lintas regional akan dapat dilaksanakan apabila hak kepemilikan sumber air (water sources property rights) yang dimiliki oleh masing-masing wilayah dapat dinyatakan secara jelas. Adanya water sources property rights yang jelas akan memunculkan posisi tawar antar wilayah, dan selanjutnya akan menciptakan mekanisme transfer air yang secara ekonomis akan efisien (Frederick, 2001).

Hal ini merupakan tantangan dalam pengelolaan sumberdaya air di masa mendatang. Pengelolaan air bukan semata-mata pada memperbesar penyediaan air yang ada dengan memperbesar kapasitas eksploitasi sumberdaya air. Namun berkaitan dengan berbagai hal. Salah satu sektor yang perlu memperoleh perhatian adalah perlunya efisiensi pemakaian air pada sektor pertanian. Saat ini penggunaan air untuk irigasi pertanian mencapai sekitar $90 \%$ dari total pemakaian air sehingga sangat boros sekali. Perlu dilakukan kajian mendalam dan spesifik lokasi untuk menemukan sumber-sumber penyediaan air baru bagi kabupaten/kota yang defisit air tinggi, baik melalui demand management maupun supply management serta peluang dilaksanakannya inter basin transfer. Dengan kondisi defisit seperti ini maka diperlukan juga kajian mendalam tentang kemungkinan dilaksanakannya perubahan dan penyesuaian alokasi antar kebutuhan, terutama perubahan alokasi untuk pemenuhan kebutuhan irigasi. Konsekuensi logis perubahan alokasi tersebut adalah berkurangnya pasokan air untuk pemenuhan irigasi sehingga tanpa adanya perubahan teknologi maka akan mengurangi luas areal layanan (command area) dan produktifitas tanaman. Untuk itu diperlukan strategi kebijakan baru dalam pengembangan irigasi di Jawa Tengah yang mempertimbangkan fenomena defisit air dan kebutuhan bahan pangan serta infrastruktur irigasi yang telah dibangun.

\section{KESIMPULAN}

Berbagai studi perhitungan keseimbangan air di Jawa Tengah menunjukkan kebutuhan air semakin meningkat sedangkan ketersediaan air semakin berkurang. Adanya perbedaaan dalam perhitungan dari studi-studi yang ada pada dasarnya disebabkan oleh karena tingkat kedetilan yang digunakan tidak sama sehingga memungkinkan timbulnya interpretasi yang salah. Sebab jika dililihat secara sepintas, seolah-olah surplus dengan ketersediaan air yang melimpah karena dari potensi yang ada yang termanfaatkan baru sekitar 41,97\%. Padahal jika dilihat lebih rinci, maka defisit air sudah banyak terjadi di berbagai daerah. Oleh 
karena itu diperlukan adanya studi lebih lanjut yag bersifat lebih komprehensif.

Dari hasil analisis, secara umum dapat diambil kesimpulan bahwa kebutuhan air untuk rumah tangga, perkotaan, industri, dan pertanian mengalami peningkatan yang signifikan. Pertambahan penduduk dan aktifitas perekonomian di satu sisi berdampak pada peningkatan kebutuhan air, namun disisi lain juga berdampak pada perubahan tata guna lahan yang mengakibatkan perubahan perilaku hidrologis. Adanya perubahan perilaku hidrologis tersebut menyebabkan perubahan pola ketersediaan air. Kondisi ini semakin diperparah oleh menurunnya daya dukung lingkungan akibat kerusakan catchment area. Hal tersebut juga meningkatkan potensi bencana yang akan mengancam keberlanjutan infrastruktur di Jawa Tengah yang dibangun dengan investasi yang sangat besar.

\section{DAFTAR PUSTAKA}

1. Abu-Zeid, M.A, 1998, Water and Sustainable Development : the Vision for World Water, Life and the Environment, Water Policy I (1998) 9-19, Elsevier Science Ltd.

2. Bappenas, 2005. Studi Prakarsa Strategis SDA untuk Mengatasi Banjir dan Kekeringan di Pulau Jawa. Tidak Diterbitkan. Jakarta

3. Bouwer, H., 2000. Integrated Water Management : Emerging Issues and Challenges, Agricultural Water Management 45 (2000) 217-228, Elsevier Science.

4. Dinar, A., 1998. Water Policy Reform : Information Needs and Implementation Obstacles. Water Policy I (1998) 367-382. Elsevier Science.

5. Flint, R.W. 2003. The Sustainable Development of Water Resources. Http: //www.sustainabledevelopmentsolutions.co $\mathrm{m}$.

6. Frederick, K.D. 2001. Water as Source of International Conflict. Http : //www.rff.org/reources_articles/files/waterwa r.htm. [28 -2- 2001].
7. Giordano, M., Zhu, Z., Cai, X., Hong, S., Zhang, X., Xue., Y. 2004. Water Management in the Yellow River Basin: Background, Current Critical Issues and Future Research Needs. Comprehensive Assessment Research Report 3. IWMI. Colombo. Srilanka.

8. Gleick, P.H., 1999. The Human Right to Water. Water Policy I (1998) 487-503. Elsevier Science Ltd.

9. Loucks, D.P. 2000. Sustainable water resources management. Water International, 25 (1) : 2-10

10. Lundin, M., S. Molander, S. , and G.M. Morrison. 1997. Indicators for The Development of Sustainable Water and Wastewater Systems. Paper for Sustainable Development Research Conference, Manchester.

11. Nazir, M. 1999. Metode Penelitian. Ghalia Indonesia. Jakarta.

12. Nugroho, S.P., 2002. Pengelolaan DAS dan Sumberdaya Air yang Berkelanjutan. Peluang dan Tantangan Pengelolaan Sumberdaya Air di Indonesia. P3-TPSLK BPPT dan HSF. Jakarta.

13. Nugroho, S.P., 2007. Analisis Neraca Air Pulau Jawa. Jurnal ALAMI Vol.12 No.1 Tahun 2007. PTLWB BPPT. Jakarta.

14. Pawitan, et al., 1996. Keseimbangan Air Hidrologi di Indonesia Menurut Kabupaten (Hydrology Water Balance of Indonesia). FMIPA IPB. Bogor.

15. Pawitan, H. 2002. Mengantisipasi Krisis Air di Indonesia Memasuki Abad 21. Peluang dan Tantangn Pengelolaan Sumberdaya Air di Indonesia. P3-TPSLK BPPT dan HSF. Jakarta.

16. Spector, B. 2001. Transboundary Environmental Disputes. Http:// www.ccpdc.org/ ubs/zart/ch9.htm.

17. Sudanti, B., (2002). Paradigma Pengelolaan Sumberdaya Air dalam era Otonomi Daerah. Dalam Pengelolaan Sumberdaya Air dalam Otonomi Daerah. Kodoatie dkk. Penerbit Andi Yogyakarta. 